\title{
Protein composition and polymorphism in the milk of Skopelos goats
}

\author{
Golfo MOATSOU ${ }^{*}$, Afroditi-Nectaria VAMVAKAKI ${ }^{\mathrm{a}}$, Daniel MOLLÉb \\ Emmanuel ANIFANTAKISa, Joëlle LÉONIL ${ }^{b}$ \\ a Laboratory of Dairy Science and Technology, Department of Food Science and Technology, \\ Agricultural University of Athens, Iera Odos 75, 11855 Athens, Greece \\ b UMR 1253 Science et Technologie du Lait et de l'CEuf, Inra-Agrocampus Rennes, \\ 65 rue de Saint Brieuc, 35042 Rennes Cedex, France
}

Received 9 May 2006 - Accepted 31 August 2006

\begin{abstract}
Individual milk samples taken from goats of the Skopelos breed of Greece were analyzed by RP-HPLC using as standards the casein fraction of milks of known genotypes. Milk samples with particular characteristics with respect to the casein fraction were further analyzed by IEF and RP-HPLC/ESI-MS. The mean total protein content $\left(36.7 \pm 2.6 \mathrm{~g} \cdot \mathrm{L}^{-1}\right)$ and the mean casein content $\left(29.7 \pm 2.3 \mathrm{~g} \cdot \mathrm{L}^{-1}\right)$ were high. The same was true for the $\alpha_{\mathrm{s} 1}$-cn fraction, which was $21.8 \%$ of the total cn fraction, whereas the $\beta$-cn percentage of total cn was $43.8 \%$. The respective values for $\alpha_{\mathrm{s} 2^{-}}$ $\mathrm{cn}$ and $\kappa$-cn were $13.7 \%$ and $13.8 \%$. These quantitative characteristics were consistent with the predominance of the strong $\alpha_{\mathrm{s} 1}$-cn variants B3, B4 and As/B1. In all samples analyzed by RP-HPLC/ ESI-MS the deleted form differing from the respective complete form by Gln78 was found at different levels of phosphorylation, with the exception of variants $F$ and D/G. The most frequent $\alpha_{\mathrm{s} 2}$-cn variant was by far variant $\mathrm{A}$ followed by variants $\mathrm{C}$ and $\mathrm{F}$, whereas compositional data implied the existence of a null allele. The detected $\beta$-cn forms were variants $\mathrm{A}$ and $\mathrm{C}$ in similar frequencies. Variant D (formerly B) of $\kappa$-cn predominated and the rare variant $\mathrm{G}$ was found. Different phosphorylation types of each casein variant and the characteristics of whey proteins were also determined.
\end{abstract}

goat milk protein / casein genotype / phosphorylation / protein quantification / polymorphism

摘要 - Skopelos 山羊奶蛋白质组成的蛋白质的多态性。以已知基因类型的乳酪蛋白为标准 品, 采用反相液相色谱分析了希腊 Skopelos 种山羊奶中蛋白质和酪蛋白的含量, 采用等电 聚焦和反相高效液相色谱-电喷雾质谱联用 (RP-HPLC/ESI-MS) 技术测定了酪蛋白的结构特 征。乳中蛋白质的含量为 $36.7 \pm 2.6 \mathrm{~g} \cdot \mathrm{L}^{-1}$, 酪蛋白的含量为 $29.7 \pm 2.3 \mathrm{~g} \cdot \mathrm{L}^{-1}, \alpha_{\mathrm{s}} 1^{-}$酪蛋白占 酪蛋白的 $21.8 \%$, 上述测定值高于文献报导的最高值, 而 $\beta$ - 酪蛋白占酪蛋白 $43.8 \%$ 低于文 献报道的最高值。 $\alpha_{\mathrm{s} 2}$ - 酪蛋白和 $\kappa$ - 酪蛋白分别占酪蛋白的 $13.7 \%$ 和 $13.8 \%$ 。在 $\alpha_{\mathrm{s} 1}$ - 酪蛋白 变异体中, 变异体 $\mathrm{B} 3, \mathrm{~B} 4$ 和 $\mathrm{As} / \mathrm{B} 1$ 占优势。所有样品经 RP-HPLC/ESI-MS 分析后证实, 除了变异体 $\mathrm{F}$ 和 $\mathrm{D} / \mathrm{G}$ 外, 其他缺失型变异体与完整型的区别是在 $\mathrm{G} \ln 78$ 位上磷酸基的不同。 $\alpha_{2}$-cn 变异体最大的基因频率是变异体 $\mathrm{A}$, 其次是变异体 $\mathrm{C}$ 和 $\mathrm{F}$, 试验证明其中可能存在无 效的等位基因。 $\beta$-酪蛋白变异体缺失型是变异体 $\mathrm{A}$ 和 $\mathrm{C}$, 他们具有相似的基因频率。在 $\kappa$ 酪蛋白中变异体 $\mathrm{D}$ 占优势, 而变异体 $\mathrm{G}$ 仅在个别品种羊奶中存在。本文还检测了每种酪蛋 白变异体不同的磷酸化类型和乳清蛋白的特性。

关键词 山羊奶蛋白 / 山羊奶酪蛋白基因型 / 磷酸化作用 / 蛋白质定量分析 / 本地山羊 / 反相高效液相色谱 - 电喷雾质谱联用 / 多态性

\footnotetext{
* Corresponding author (通讯作者): mg@aua.gr
} 
Résumé - Polymorphisme des protéines du lait de chèvre de la race Skopelos. Des laits individuels de chèvres de Skopelos (Grèce) ont été analysés par RP-HPLC et les profils protéiques ont été comparés avec ceux issus de lait de chèvres de génotypes connus au locus $\alpha_{s 1}$. Les échantillons qui présentaient des caractéristiques particulières de leur fraction caséique ont été analysés par IEF et RP-HPLC/ESI-MS. Les teneurs moyennes en protéines totales $\left(36,7 \pm 2,6 \mathrm{~g} \cdot \mathrm{L}^{-1}\right)$, et en caséines $\left(29,7 \pm 2,3 \mathrm{~g} \cdot \mathrm{L}^{-1}\right)$, étaient plus élevées que dans les laits des races hautement sélectionnées. Le pourcentage en $\alpha_{\mathrm{s} 1}$-cn représentait $21,8 \%$ des caséines totales, tandis que celui de la $\beta$-cn atteignait $43,8 \%$. Les pourcentages en $\alpha_{\mathrm{s} 2}$-cn et $\kappa$-cn étaient respectivement $13,7 \%$ et $13,8 \%$. Ces caractéristiques quantitatives étaient corrélées avec la prédominance des variants forts $\mathrm{B} 3$, B4 et As/B1 de la $\alpha_{s 1}$-cn. Dans tous les échantillons analysés par RP-HPLC/ESI-MS, la forme déplétée en Gln78 de la $\alpha_{\mathrm{s} 1}$-cn présentait plusieurs niveaux de phosphorylation, à l'exception des variants $\mathrm{F}$ et $\mathrm{D} / \mathrm{G}$. Le variant le plus abondant de la $\alpha_{s}$-cn était le variant $A$ suivi par les variants $C$ et $F$. Les variants $A$ et $\mathrm{C}$ de la $\beta$-cn ont été trouvés en fréquences similaires. Le variant $\mathrm{D}$ (antérieurement dénommé $\mathrm{B}$ ) de la $\kappa$-cn était prédominant bien que le variant rare $G$ était aussi trouvé. Plusieurs niveaux de phosphorylation de chacun de ces variants ont été aussi mis en évidence, ainsi que les principales caractéristiques des protéines du sérum.

polymorphisme / variant proteique / lait de chèvre / caséine / génotype / phosphorylation

\section{INTRODUCTION}

Skopelos goats are an autochthonous Greek breed [18] with a population of about 4500 animals raised in central Greece, mainly on Skopelos island, with a daily average milk production of $1.65 \mathrm{~kg}$ per animal and an average lactation period of 202 days. They are considered as an endangered dairy goat breed protected by the law.

It is well established that the complex qualitative and quantitative variability in goat caseins affects both the composition and technological behavior of milk. Seventeen $\alpha_{\mathrm{s} 1}$-casein variants associated with high $\alpha_{\mathrm{s} 1}$-casein content $\left(3.6 \mathrm{~g} \cdot \mathrm{L}^{-1}\right.$ per allele; A, B1, B2, B3, B4, C, L and M or $4.2 \mathrm{~g} \cdot \mathrm{L}^{-1}$ per allele, $\left.\mathrm{H}\right)$ or medium $\left(1.6 \mathrm{~g} \cdot \mathrm{L}^{-1}\right.$ per allele; $\mathrm{E}$ and $\mathrm{I})$ or low $\left(0.6 \mathrm{~g} \cdot \mathrm{L}^{-1}\right.$ per allele; $\mathrm{D}, \mathrm{F}$ and $\mathrm{G})$ or no $\alpha_{\mathrm{s} 1}$-casein $\left(\mathrm{O}^{1}, \mathrm{O}^{2}\right.$ and $\mathrm{N}$ ) have been so far reported [4, 28, 42]. An additional source of $\alpha_{\mathrm{s} 1}$-casein polymorphism is the simultaneous existence of deleted forms due to alternative splicing [16].

Five of the alleles of $\alpha_{\mathrm{s} 2}$-casein (A, B, C, $\mathrm{E}$ and $\mathrm{F}$ ) are associated with a production of $2.5 \mathrm{~g} \cdot \mathrm{L}^{-1} \alpha_{\mathrm{s} 2}$-casein per allele, one with decreased synthesis of $\alpha_{\mathrm{s} 2}$-casein and one with zero $\alpha_{\mathrm{s} 2}$-casein content $[5,23,40,41]$. An additional variant $(G)$ shown on isoelectric focusing gels has been reported by Erhardt et al. [15].

The four genetic variants of goat $\beta$ casein are associated with a normal $\beta$-casein content in milk, whereas there are two null alleles and one silent allele [12, 13, $17,25,35,37]$. There are 13 variants of goat $\kappa$-casein at the protein level and three silent alleles [20, 39, 50].

Many of the above-mentioned variants have been recently identified by using DNA typing of indigenous breeds from Southern Italy, West Africa or the Near East. It has been shown that goat casein variants differ among breeds and that they are related to region $[6,7,20,22,39,44,47]$.

The aim of this research work was to study the protein fraction of the milk of the Skopelos goat breed of Greece. For this purpose, individual milk samples were taken from goats of the Skopelos, which were analyzed by RP-HPLC, using as standards the casein fraction of milks of known genotypes in the $\alpha_{s 1}$ locus [35]. Their qualitative (number of peaks and retention time) and their quantitative characteristics (quantity of individual proteins) were studied. A number of samples with particular protein profiles were chosen to be further analyzed by IEF and RP-HPLC/ESI-MS, with the aim of characterizing them in detail.

\section{MATERIALS AND METHODS}

\subsection{Milk samples}

Sixty individual milks were randomly collected after the complete morning milking 
of goats of the Skopelos breed. After the addition of sodium azide $\left(0.4 \mathrm{~g} \cdot \mathrm{L}^{-1}\right)$, the milk samples were cooled down. A part of them was used for the compositional analyses and the other part was skimmed by centrifugation at $2000 \times g$ for $30 \mathrm{~min}$ at $4{ }^{\circ} \mathrm{C}$. Total protein contents of milk samples were determined by means of an infrared spectroscopy apparatus (Milkoscan $133 \mathrm{~A} / \mathrm{S} \mathrm{N}$, Foss Electric, Hillerod, Denmark) that was calibrated against the reference methods using goat's milks of different composition.

\subsection{RP-HPLC of milk samples}

The defatted milk samples were analyzed by RP-HPLC with the aim of visualizing and evaluating their protein profile. A Vydac C4 214 TP $54154.6 \mathrm{~mm} \times 150 \mathrm{~mm}$ column (Separation group, Hesperia, CA, USA) was used. The HPLC system consisted of the Waters 600E pump (Waters, 34 Marple Street, Milford, MA, USA) and Millenium v. 3.05.01 software (1998, Waters). Solvent A was $1060 \mu \mathrm{L} \cdot \mathrm{L}^{-1}$ trifluoroacetic acid in ultrapure water and Solvent $B$ was $1 \mathrm{~mL}$ TFA, $800 \mathrm{~mL}$ acetonitrile and $200 \mathrm{~mL}$ ultrapure water. The flow rate was $1 \mathrm{~mL} \cdot \mathrm{min}^{-1}$, the analyses were carried out at $40^{\circ} \mathrm{C}$ and the eluent was monitored at $214 \mathrm{~nm}$. A linear gradient from 350 to $620 \mathrm{~mL} \cdot \mathrm{L}^{-1}$ (from $35 \%$ to $62 \%$ ) solvent B within 54 min was applied [21, 35]. Samples were prepared as follows: $0.5 \mathrm{~mL}$ of defatted milk was dissolved in $1 \mathrm{~mL}$ buffer, $\mathrm{pH} 7.0\left(100 \mathrm{mmol} \cdot \mathrm{L}^{-1}\right.$ Tris, $8 \mathrm{~mol} \cdot \mathrm{L}^{-1}$ urea, $13 \mathrm{~g} \cdot \mathrm{L}^{-1}$ trisodium citrate and $20 \mathrm{mmol} \cdot \mathrm{L}^{-1}$ dithiothreitol adjusted to $\mathrm{pH} 7.0$ by $\mathrm{HCl}$ ). After $1 \mathrm{~h}$ at $37^{\circ} \mathrm{C}, 10 \mathrm{~mL}$ of Solvent A containing $6 \mathrm{~mol} \cdot \mathrm{L}^{-1}$ urea were added to the sample solution and the $\mathrm{pH}$ was adjusted to 2.1-2.2 with the addition of $0.5 \mathrm{~mL}$ of a TFA solution $\left(100 \mathrm{~mL} \cdot \mathrm{L}^{-1}\right)$. After filtration through a $0.45-\mu \mathrm{m}$ filter (Millipore Corporation, Bedford MA, USA), $50 \mu \mathrm{L}$ of sample were injected. Two independent preparations of each sample were analyzed and the profiles were compared with those obtained from the analyses of whole casein standards containing known casein genotypes ( $\kappa$-casein $\mathrm{AA}, \alpha_{\mathrm{s} 2}$-casein $\mathrm{AA}, \alpha_{\mathrm{s} 1^{-}}$ casein $\mathrm{AA}, \mathrm{EE}$ and $\mathrm{O}^{1} \mathrm{O}^{1}$, and $\alpha_{\mathrm{s} 1}$-casein CC).

\subsection{RP-HPLC/ESI-MS of selected milk samples}

After the assessment of the chromatographic profiles, 25 samples were selected for further analysis by RP-HPLC/ESI-MS. The selection was based on the retention time and on the quantification data obtained after the integration of their protein profiles (Sect. 2.2). A Vydac C4 214 TP $52152.1 \mathrm{~mm} \times 150 \mathrm{~mm}$ column was used in a system coupling on-line RP-HPLC and ESI-MS. RP-HPLC was carried out on a Hewlett Packard 1100 system (Agilent Technologies, Massy, France) at a flow rate of $0.25 \mathrm{~mL} \cdot \mathrm{min}^{-1}$ at $40{ }^{\circ} \mathrm{C}$, and the detection was by absorbance at $214 \mathrm{~nm}$ and by total ion current. Solvent A was $1060 \mu \mathrm{L} \cdot \mathrm{L}^{-1}$ trifluroacetic acid (TFA) in ultrapure water and Solvent B was $1 \mathrm{~mL}$ TFA, $800 \mathrm{~mL}$ acetonitrile and $200 \mathrm{~mL}$ ultrapure water. The elution conditions were as follows: $370 \mathrm{~mL} \cdot \mathrm{L}^{-1}$ solvent $\mathrm{B}(37 \%)$ for $5 \mathrm{~min}$, then a linear gradient from 370 to $570 \mathrm{~mL} \cdot \mathrm{L}^{-1}$ solvent B (from 37 to $57 \%$ ) within $37.5 \mathrm{~min}$ was applied. The column was directly interfaced with a Sciex API III Plus mass spectrometer (Perkin-Elmer-Sciex, Thornhill, Ontario, Canada), through a post-flow splitter permitting the introduction of only $1 / 10$ of the HPLC eluate into the mass spectrometer. The ion source voltage and the orifice voltage were set at $4-5 \mathrm{kV}$ and $70 /$ $90 \mathrm{~V}$, respectively. Positive ion mode was used and mass scans were acquired over a $\mathrm{m} / \mathrm{z}$ range of 500-2400 with a step size of $0.3 \mathrm{~g} \cdot \mathrm{mol}^{-1}$ and a dwell time of $1 \mathrm{~ms}$ per step. The charge number of the multicharge ions, the deconvoluted mass spectra and the proteins $\mathrm{Mr}$ (mass) determination were obtained using the BioMultiView software 1.3.1. (PE-SCIEX). Fifty mg of lyophilized milk was dissolved in $800 \mathrm{~mL}$ buffer, $\mathrm{pH}$ $7.0\left(100 \mathrm{mmol} \cdot \mathrm{L}^{-1}\right.$ Tris, $8 \mathrm{~mol} \cdot \mathrm{L}^{-1}$ urea, $13 \mathrm{~g} \cdot \mathrm{L}^{-1}$ trisodium citrate and $20 \mathrm{mmol} \cdot \mathrm{L}^{-1}$ dithiothreiol adjusted to $\mathrm{pH} 7.0$ by $\mathrm{HCl}$ ). After $1 \mathrm{~h}$ at $37^{\circ} \mathrm{C}, 3 \mathrm{~mL}$ of Solvent A containing $4 \mathrm{~mol} \cdot \mathrm{L}^{-1}$ urea were added to the sample solution and the $\mathrm{pH}$ was adjusted to 2.1-2.2 with the addition of $150 \mathrm{~mL}$ of a TFA solution $\left(100 \mathrm{~mL} \cdot \mathrm{L}^{-1}\right)$. After filtration through a $0.45-\mu \mathrm{m}$ filter (Millipore Corporation, Bedford MA, USA), $50 \mu \mathrm{L}$ of sample were injected. 
Table I. Quantitative characteristics of the protein fraction (expressed in $\mathrm{g} \cdot \mathrm{L}^{-1}$ ) of individual goat milk samples $(\mathrm{n}=57)$ from the Skopelos breed.

\begin{tabular}{|c|c|c|c|c|c|c|c|c|c|}
\hline & $\begin{array}{c}\text { Total } \\
\text { protein }^{\mathrm{a}}\end{array}$ & $\kappa-c n^{b}$ & $\alpha_{\mathrm{s} 2}-\mathrm{cn}^{\mathrm{b}}$ & $\alpha_{\mathrm{s} 1}-\mathrm{cn}{ }^{\mathrm{b}}$ & $\gamma-\mathrm{cn}^{\mathrm{b}}$ & $\beta-c n^{b}$ & Total $\mathrm{cn}^{\mathrm{b}}$ & $\mathrm{a}-\mathrm{LA}^{\mathrm{b}}$ & b-Lgb \\
\hline mean & 36.65 & 4.09 & 4.07 & 6.47 & 2.0 & 13.0 & 29.7 & 1.37 & 2.14 \\
\hline SD & 2.63 & 0.56 & 0.69 & 1.96 & 0.54 & 1.15 & 2.28 & 0.22 & 0.45 \\
\hline $\min$ & 31.3 & 3.12 & 2.62 & 1.31 & 1.15 & 10.3 & 25.0 & 0.94 & 1.37 \\
\hline $\max$ & 42.3 & 5.61 & 5.95 & 10.1 & 3.41 & 15.5 & 34.6 & 2.01 & 3.89 \\
\hline
\end{tabular}

a Estimated by Milkoscan (Sect. 2.1).

b Estimated by the area of the chromatographic peaks and by the compositional data (Sect. 3.1).

\subsection{Isoelectric focusing (IEF) of whole casein}

Whole casein prepared by acidification at $\mathrm{pH} 4.2$ using $0.1 \mathrm{~mol} \cdot \mathrm{L}^{-1} \mathrm{HCl}$, of samples with characteristic protein profiles, was analyzed by isoelectric focusing on ultrathin polyacrylamide gels, as described by Moatsou et al. [31]. For comparison reasons, whole casein fractions of the standard milks of known genotypes were analyzed by the same method.

\subsection{Statistical analysis}

The software Statgraphics Plus for Windows 2.1 (Manugistics, Inc. Rockville, Maryland, USA) was used for the statistical analysis. Principal component analysis (PCA) was applied with the aim of grouping the milk samples regarding their $\alpha_{\mathrm{s} 1}$-cn and $\alpha_{\mathrm{s} 2}$-cn characteristics. The factors with eigenvalues $>1$ were retained.

\section{RESULTS AND DISCUSSION}

The elution times of $\alpha$-la and $\beta$-lg were determined after the analysis of acid goat's wheys and individual whey proteins [30]. The elution time of $\gamma$-casein was determined after the analysis of a plasmin hydrolysate of goat $\beta$-cn [31]. The quantification of the individual protein fraction was based on the chromatographic areas of the peaks and on the total protein content of each sample. Three samples were not included in the study due to proteolysis.
The quantitative characteristics of the milk samples from the Skopelos breed are presented in Table I and some characteristic RP-HPLC profiles are presented in Figure 1. The total protein content, $36.7 \pm 2.6 \mathrm{~g} \cdot \mathrm{L}^{-1}$, and the casein content, $29.7 \pm 2.3 \mathrm{~g} \cdot \mathrm{L}^{-1}$, were higher than those of international highly selected breeds [33, 34, 46] and similar to those of the milk from indigenous Greek goats $[1,45]$. The same was true for the $\alpha_{\mathrm{s} 1}$-cn, which was $21.8 \%$ of the total cn fraction, compared with the 8-17\% reported for highly selected breeds. On the contrary, the $\beta$-cn percentage of total $\mathrm{cn}$ of highly selected breeds, $48-60 \%$, is higher compared with the $43.8 \%$ of the present milk.

The retention time of each peak was calculated relatively to $\beta$-cn to avoid variation from day to day, and it was symbolized as rRT. They were compared with the respective rRTs of goat casein of standard samples with known genotypes (Tab. II).

Twenty-five samples with profiles with particular characteristics or with marginal contents of total protein or individual caseins were chosen to be further analyzed by RP-HPLC/ESI-MS. For the assignment of the experimental masses of the casein peaks to the known variants, we took into consideration: (i) the known theoretical masses if the difference was $<0.03 \%$, and (ii) the peak area, since several $\alpha_{\mathrm{s} 1}$-cn variants share very similar molecular masses and they have the same rRTs; but they have different levels of expression. 
Table II. Retention times relative to $\beta$-cn (rRT) of individual goat caseins in the RP-HPLC profiles of standard samples with known genotypes.

\begin{tabular}{lcccccc}
\hline & $\kappa-c n A$ & $\kappa-c n D^{\mathrm{a}}$ & $\alpha_{\mathrm{s} 2}$-cn A/B & $\alpha_{\mathrm{s} 2}$-cn C & $\alpha_{\mathrm{s} 1}$-cn E & $\alpha_{\mathrm{s} 1}$-cn A \\
\hline $\mathrm{n}^{\mathrm{b}}$ & 6 & 21 & 21 & 6 & 11 & 12 \\
mean & 18.13 & 17.82 & 13.94 & 12.16 & 5.11 & 4.19 \\
$\mathrm{SD}$ & 0.46 & 0.55 & 0.79 & 0.51 & 0.28 & 0.27 \\
\hline
\end{tabular}

a Formerly B according to the nomenclature proposed by Jann et al. [20].

b Number of chromatographic runs.

\section{1. $\alpha_{\mathrm{s} 1}$-casein}

The defective variants $\mathrm{F}, \mathrm{D}$ and $\mathrm{G}$ could not be determined by ESI-MS or by IEF with certainty, especially in the heterozygous condition, due to their very low quantities (Fig. 1), because they are associated with $0.6 \mathrm{~g} \cdot \mathrm{L}^{-1} \alpha_{\mathrm{s} 1}$-cn production per allele. Furthermore, the D and $G$ variants cannot be distinguished from each other, since they differ by 2.7 mass units. However, D/G variants were determined in the heterozygous condition in 5 out of the 25 samples analyzed by RP-HPLC/ESI-MS: in 2 samples with the strong $\alpha_{\mathrm{s} 1}$-cn B3, in 2 with the strong $\alpha_{\mathrm{s} 1}$-cn B4, and in one of them with the defective $\alpha_{\mathrm{s} 1}$-cn F. Therefore, since the expression of weak variants could not be clearly distinguished from the expression of the null variants using the chromatographic profiles of the milks, the term defective variant was used to indicate their existence in some samples.

For the interpretation of the $\alpha_{\mathrm{s} 1}$-cn results, the total of 57 milks were separated into five groups, taking into consideration the number of $\alpha_{\mathrm{s} 1}$-cn peaks (1 or 2) and the rRT, as shown in Table III. Within each group, there were different levels of $\alpha_{\mathrm{s} 1}$-cn quantities, which were pointed out with the aid of a Principal Component Analysis plot based on the $\alpha_{\mathrm{s} 1}$-cn content, $\beta$-cn content and on the $\beta-\mathrm{cn} / \alpha_{\mathrm{s} 1}-\mathrm{cn}$ ratio of the samples. The genetic variants of $\alpha_{\mathrm{s}} 1^{-\mathrm{cn}}$ indicated in Table III were determined in the 25 samples that were further analyzed by RP-HPLC/ ESI-MS.

The rRT of group A corresponds to the rRT of variant E (Tab. II). However, the $\alpha_{\mathrm{s} 1}$-cn content of the samples of this group was not medium and experimental masses corresponding to strong variants B3 and B4 were also detected. Variants B3, B4 and E cannot be separated in the RP-HPLC profiles [3, 4, 9, 10, 21]. Furthermore, E and B4 have the same amino acid composition but different levels of expression ( $\mathrm{E}$ is a medium and B4 is a strong variant). When only a strong variant was detected in the samples with medium $\alpha_{\mathrm{s} 1^{-c n}}$ quantity, it was considered that it existed in the heterozygous condition along with a defective variant.

The same strategy was followed for the interpretation of the $\alpha_{\mathrm{s} 1}$-cn fraction of milks of group B, bearing in mind that the strong As variant has the same amino acid composition as the medium I variant, and that variants As and B1 with $9 \mathrm{P}$ co-elute each other and differ by one mass unit. However, in variant A there is a potential tenth phosphorylation site at Ser75 [29] that is eliminated in variant B1 due to $\mathrm{Glu} / \mathrm{Gln}$ replacement at position 77 . The quantification characteristics of Table III implied the existence of the strong variants As/B1 in the homozygous form in one sample with $8.5 \mathrm{~g} \cdot \mathrm{L}^{-1} \alpha_{\mathrm{s} 1^{-}}$cn or the existence of the strong variant in the heterozygous condition with the medium variant I in the sample with $5.89 \mathrm{~g} \cdot \mathrm{L}^{-1} \alpha_{\mathrm{s} 1}$-cn. Similarly, it was evident that in the four samples with mean $\alpha_{\mathrm{s} 1}$-cn content of $3.82 \mathrm{~g} \cdot \mathrm{L}^{-1}$, the strong variant As/B1 existed with a defective variant or the medium variant I existed in the homozygous condition.

In group $\mathrm{C}$, the existence of a strong variant along with a medium variant was also evident in the RP-HPLC profiles due to the great difference between the heights of the relevant peaks (Fig. 1). Twenty-eight milks out of 57 had a high $\alpha_{\mathrm{s} 1}$-cn content, ranging from 7.5 to $8.5 \mathrm{~g} \cdot \mathrm{L}^{-1}$, indicating the existence 


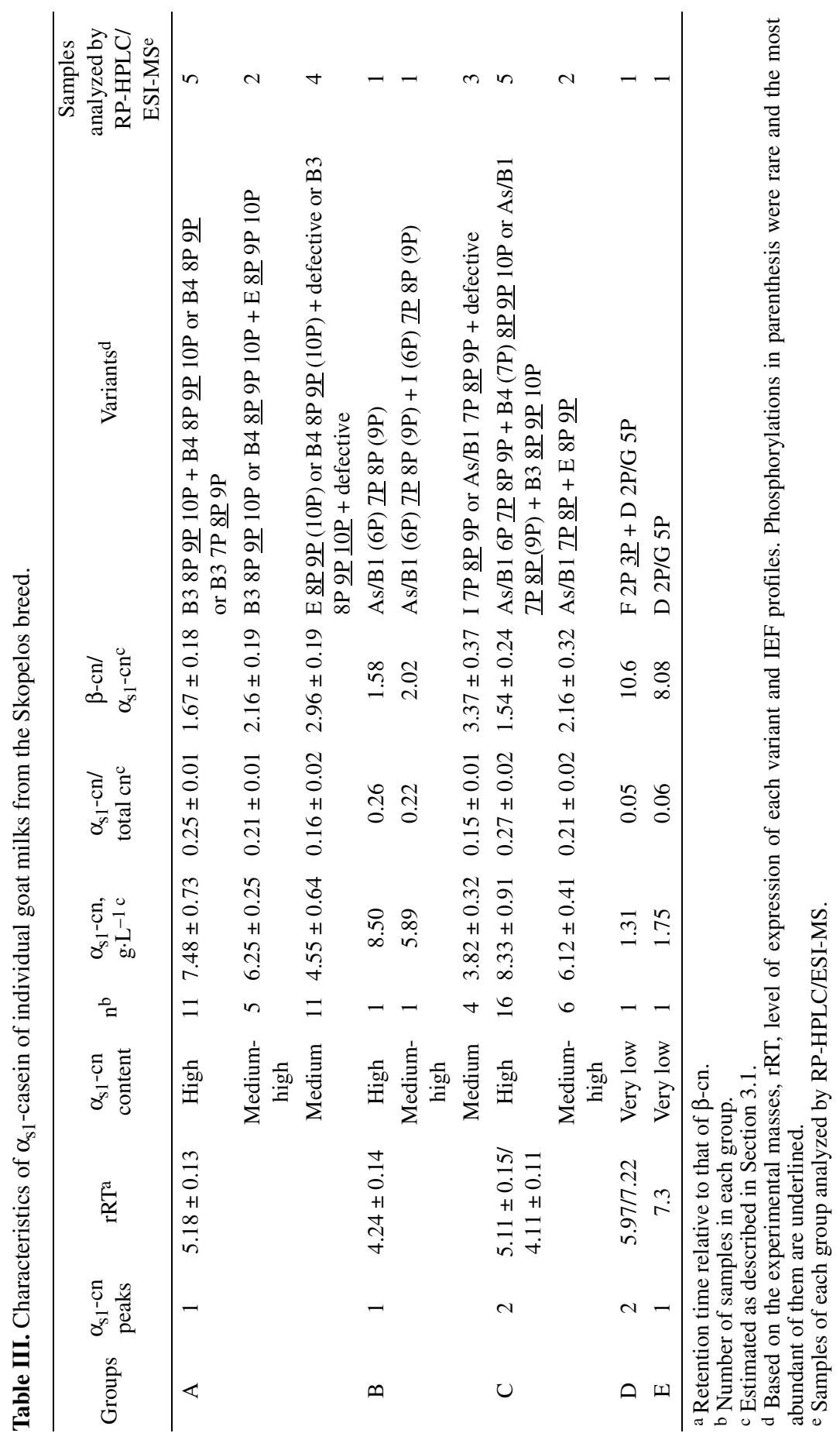



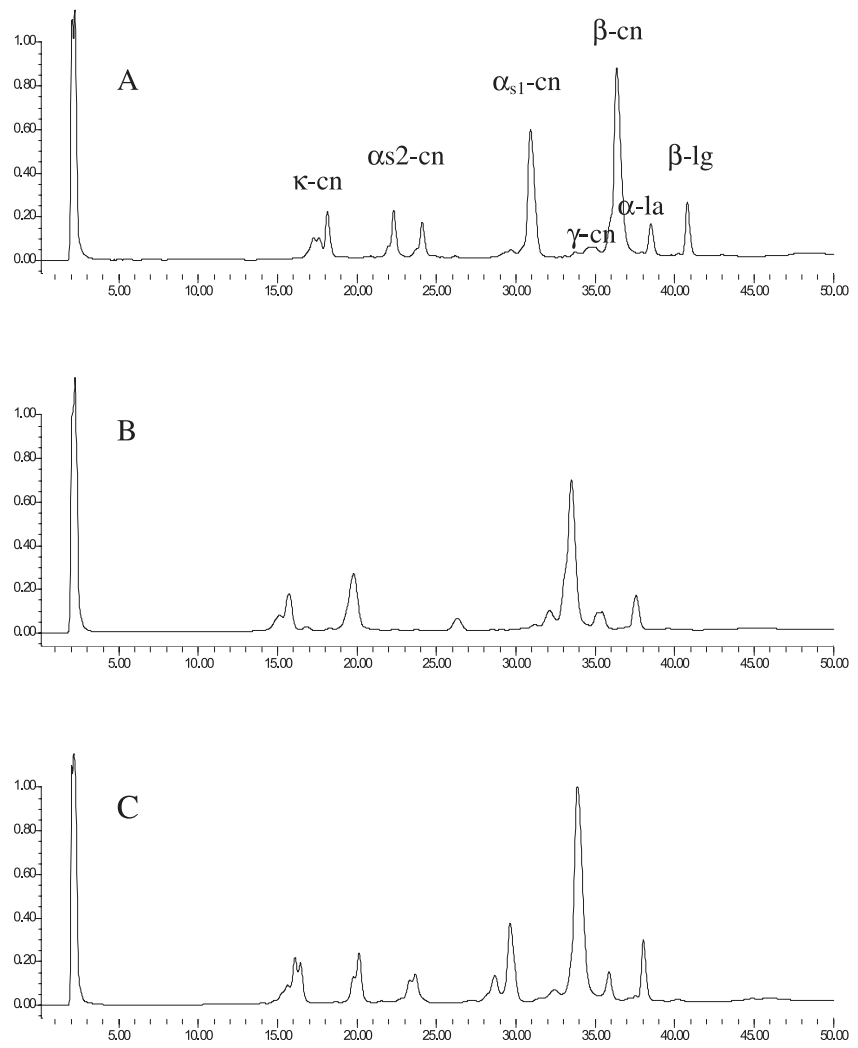

Figure 1. Some characteristic RP-HPLC profiles (A214) of individual goat milk samples from the Skopelos breed. Column: Vydac C4 214 TP 5415; elution conditions: as described in Section 2.2. The genotypes were determined by RP-HPLC/ESI-MS (Sect. 2.3). A: $\kappa$-cn DD, $\alpha$ s2-cn AC, $\alpha_{\mathrm{s} 1}{ }^{-}$ cn B3B4, $\beta$-cn AA; B: $\kappa-c n$ DD, $\alpha$ s2-cn AA, $\alpha_{\mathrm{s} 1^{-}} \mathrm{cn}$ D/G, $\beta-\mathrm{cn}$ CC; C: $\kappa$-cn DG, $\alpha$ 2-cn AF, $\alpha_{\mathrm{s} 1^{-}}$ cn As/B1E, $\beta$-cn AC.

of strong variants in the homozygous condition. Twelve milks had a medium-high content (from 5.9 to $6.3 \mathrm{~g} \cdot \mathrm{L}^{-1}$ ), which implied the existence of a strong and a medium variant. Only two milks had a very low content, which corresponds to defective variants.

The strong variants determined by RPHPLC/ESI-MS were mainly B3 (in 7 samples out of 25) and B4 (in 10 samples out of 25), followed by As or B1 (in 2 samples out of 25). The combination of rRT and $\alpha_{\mathrm{s} 1^{-}}$ cn quantity showed that the medium variants were $\mathrm{E}$ and I. Therefore, the A and B variants were predominant, either in com- binations with each other or with medium or defective variants, in accordance with the reports of Enne et al. [14], Martin et al. [28], Chianese et al. [8], Sacchi et al. [44] and Marletta et al. [27], on the abundance of strong $\alpha_{\mathrm{s} 1^{-}} \mathrm{cn}$ variants in the autochthonous dairy goat breeds of the Mediterranean region.

In all samples analyzed by RP-HPLC/ ESI-MS the deleted form differing from the respective complete form by Gln78 was found at different levels of phosphorylation, with the exception of variants $F$ and D/G. No other deleted forms were detected in the profiles, probably due to their low quantities. 
Ferranti et al. [16] report that apart from genetic polymorphism, mature goat $\alpha_{\mathrm{s} 1}$-cn exists as a mixture of at least seven molecular species with different peptide chain lengths, as a result of alternative skipping. The main component corresponds to the 199-residue-long form and the deleted proteins differ from the complete one by the absence of peptides 141-148, 110-117 or Gln78 or a combination of such deletions.

The main phosphorylation levels of $\alpha_{\mathrm{s} 1}$ $\mathrm{cn} \mathrm{B} 3, \mathrm{~B} 4$ and $\mathrm{E}$ were three from $8 \mathrm{P}$ to $10 \mathrm{P}$, the most abundant (based on intensity TIC) being the $9 \mathrm{P}$ form or the $8 \mathrm{P}$ form for the latter, whereas As/B1 were present in 4 phosphorylation levels from $6 \mathrm{P}$ to $9 \mathrm{P}$, the most abundant being the $7 \mathrm{P}$ form. These results were in accordance with previous reports $[35,38,48]$.

\section{2. $\alpha_{\text {s2 }}$-casein}

The characteristics of the $\alpha_{\mathrm{s} 2}$-casein fraction of the individual milks are shown in Table IV. The presentation was based on the rRT of $\alpha_{\mathrm{s} 2}$-cn peaks in RP-HPLC profiles, on their quantity $\left(\mathrm{g} \cdot \mathrm{L}^{-1}\right)$ and on the ESI-MS analyses. Accordingly, samples were divided into four groups with regard to $\mathrm{rRT}$ of the number (1 or 2) of $\alpha_{\mathrm{s} 2}$-cn peaks. Most of them, 34 out of 57, were homozygotes for variant $\mathrm{A}$, whereas variant A was present in 55 samples. This finding was in accordance with several reports regarding the frequency of variant $\mathrm{A}$ in international [5] or native [15, 26, 27, 40, $41,44]$ breeds.

A PCA plot based on $\alpha_{\mathrm{s} 2}$-cn $\left(\mathrm{g} \cdot \mathrm{L}^{-1}\right)$ content, on $\beta$-cn $\left(g \cdot \mathrm{L}^{-1}\right)$ and on the ratio of $\beta$-cn to $\alpha_{\mathrm{s} 2}-\mathrm{cn}$ showed that there were two levels of $\alpha_{s 2}$-cn content within the total of samples with one $\alpha_{\mathrm{s} 2}$-cn peak, that were at first considered as homozygotes for variant A or C. This plot implied the existence of a null $\alpha_{\mathrm{s} 2}$-cn variant in the heterozygous condition in 9 samples out of 57.

The second most frequent variant was variant $\mathrm{C}$ in the heterozygous condition with null variant (group B) or with variant A (group C). Finally, the least frequent was the variant $\mathrm{F}$, that was present only in the heterozygous condition (group D), similarly to the $\alpha_{\mathrm{s} 2}$-cn of individual milks from the
Indigenous Greek breed (data submitted for publication). Variant $F$ is an abundant $\alpha_{\mathrm{s} 2}$-cn variant in Italian goat breeds [26, 27, 40, 44].

The $\alpha_{\mathrm{s} 2}-\mathrm{cn}$ is the most phosphorylated casein and in most cases it has been found with 7-11P, the most abundant type being $11 \mathrm{P}$, as reported by Pierre et al. [38] and Neveu et al. [35]. In 4 samples out of 25 analyzed by RP-HPLC/ESI-MS, types with $12 \mathrm{P}$ and $13 \mathrm{P}$ were observed, as reported by Trujillo et al. [48]. The differentiation of variant $B$ of $\alpha_{\mathrm{s} 2}$-cn was not possible, because it co-elutes with variant $\mathrm{A}$ and has almost the same mass. However, it has $1 \mathrm{P}$ lower than A, due to amino acid substitution, Glu64 $\rightarrow$ Lys64, that affects phosphorylation site Ser62 [35], but no $\alpha_{\mathrm{s} 2}$-cn with such a phosphorylation pattern was found by ESI-MS analysis. Moreover, some randomly selected samples were analyzed by IEF since $\alpha_{\mathrm{s} 2}$-cn $\mathrm{A}$ and $\mathrm{B}$ have different profiles. No sample was assigned to variant $\mathrm{B}$, similarly to individual milks from the Indigenous Greek breed (data submitted for publication).

\section{3. $\beta$-casein}

The mean $\beta$-cn content of the samples was $13 \pm 1.15 \mathrm{~g} \cdot \mathrm{L}^{-1}$, and in 43 out of a total of 57 , it ranged from 11.6 to $14.2 \mathrm{~g} \cdot \mathrm{L}^{-1}$.

Goat $\beta$-cn variants could not be distinguished from each other because they coelute each other in the RP-HPLC profiles, have similar IEF profiles and they are associated with a normal $\beta$-cn content. Therefore, in Table $\mathrm{V}$, only the 25 samples analyzed by ESI-MS are presented. Variants A [43] and C [35] were present in both homozygous and heterozygous forms in 3 phosphorylation levels, the most abundant being $5 \mathrm{P}$ and $6 \mathrm{P}$ in almost similar quantities. Furthermore, the quantification data did not imply the existence of a null allele [13] in the heterozygous condition. The $\beta-\mathrm{Cn}$ variants $\mathrm{A}$ and $\mathrm{C}$ were almost equally present.

In one sample, an unknown mass of 23876 was found in the $\beta$-cn peak along with variant $C$, in two levels of phosphorylation, which has been also found in the milk of the Indigenous Greek breed and is under investigation. 


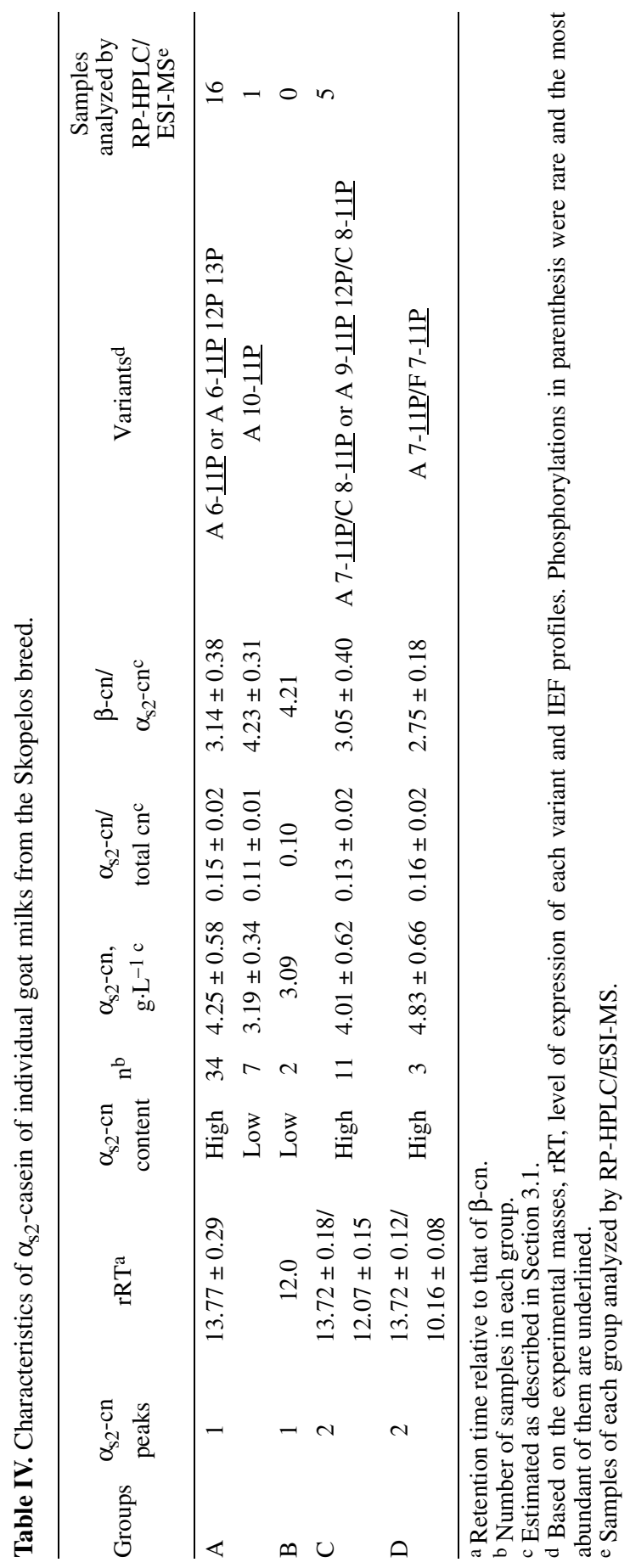


Table V. Types of $\beta$-cn in individual goat milks from the Skopelos breed determined by RP-HPLC/ ESI-MS.

\begin{tabular}{|c|c|c|c|}
\hline Variant $^{\mathrm{a}}$ & $\mathrm{n}^{\mathrm{b}}$ & $\beta$-cn, $g \cdot L^{-1}$ c & $\beta-\mathrm{cn} /$ total cn ${ }^{c}$ \\
\hline A $4 \mathrm{P} \underline{5 \mathrm{P}} \underline{6 \mathrm{P}}$ & 7 & $12.9 \pm 1.3$ & $0.44 \pm 0.06$ \\
\hline $\mathrm{C} 4 \mathrm{P} \underline{5 \mathrm{P}} \underline{6 \mathrm{P}}$ & 8 & $12.9 \pm 0.7$ & $0.46 \pm 0.05$ \\
\hline A $4 \mathrm{P} \underline{5 \mathrm{P}} \underline{6 \mathrm{P}}+\mathrm{C} 4 \mathrm{P} \underline{5 \mathrm{P}} \underline{6 \mathrm{P}}$ & 9 & $12.9 \pm 1.5$ & $0.42 \pm 0.06$ \\
\hline C $\underline{5 \mathrm{P}} \underline{6 \mathrm{P}}+$ unknown & 1 & 12.23 & 0.44 \\
\hline
\end{tabular}

a Based on the experimental masses, retention times relative to $\beta$-cn (rRTs) and IEF profiles. Phosphorylations in parenthesis were rare and the most abundant of them are underlined.

b Number of samples with this type of $\beta$-cn.

${ }^{\mathrm{c}}$ Estimated as described in Section 3.1.

Table VI. Types of $\kappa-\mathrm{cn}$ in individual goat milks from the Skopelos breed.

\begin{tabular}{lccc}
\hline Variant $^{\mathrm{a}}$ & $\mathrm{n}^{\mathrm{b}}$ & $\kappa-\mathrm{cn}, \mathrm{g} \cdot \mathrm{L}^{-1 \mathrm{~d}}$ & $\kappa$-cn/total cn $\mathrm{d}$ \\
\hline $\mathrm{A}(1 \mathrm{P}) \underline{2 \mathrm{P}}$ & 1 & 3.8 & 0.12 \\
$\mathrm{D}^{3} 1 \mathrm{P} \underline{2 \mathrm{P}}$ & 18 & $4.0 \pm 0.5$ & $0.15 \pm 0.02$ \\
$\mathrm{~A}(1 \mathrm{P}) \underline{2 \mathrm{P}}+\mathrm{D}^{3} 1 \mathrm{P} \underline{2 \mathrm{P}}$ & 4 & $3.9 \pm 0.1$ & $0.14 \pm 0.005$ \\
$\mathrm{D}^{3}(1 \mathrm{P}) \underline{2 \mathrm{P}}+\mathrm{G}(1 \mathrm{P}) \underline{2 \mathrm{P}}$ & 2 & 3.8 & 0.17 \\
\hline
\end{tabular}

a Based on the experimental masses, retention times relative to $\beta$-cn (rRTs) and IEF profiles. Phosphorylations in parenthesis were rare and the most abundant of them are underlined.

$\mathrm{b}$ Number of samples with this type of $\kappa-\mathrm{cn}$.

c Formerly B variant, according to nomenclature proposed by Jann et al. [20].

$\mathrm{d}$ Estimated as described in Section 3.1.

\section{4. $\kappa$-casein}

The glycosylated forms are eluted just before the main peak [32]; therefore, only the main peak (Fig.1) was taken into consideration for the interpretation of the ESIMS results. The presentation in Table VI is according to the most recent nomenclature, proposed by Jann et al. [20], in which the former B variant [50] has been renamed as $\mathrm{D}$ and vice versa. The goat $\kappa$-cn variants were not separated on the C4 column and on the IEF gels. In fact, Prinzenberg et al. [39] report that the $\kappa-\mathrm{Cn}$ variants are grouped into 2 visible IEF patterns, according to their isoelectric points: $\mathrm{A}^{\mathrm{IEF}}$ (variants A, B, C, F, G, H, I, J and L) and B ${ }^{\mathrm{IEF}}$ (variants $\mathrm{D}, \mathrm{E}, \mathrm{K}$ and $\mathrm{M}$ ).

The mean $\kappa$-cn content of the samples was $4.09 \pm 0.56 \mathrm{~g} \cdot \mathrm{L}^{-1}$, and in 48 out of a total of 57 , it ranged from 3.1 to $4.8 \mathrm{~g} \cdot \mathrm{L}^{-1}$. The different $\kappa$-cn alleles have not been associated with differences in their level of expression. However, Chianese et al. [8] report that $\mathrm{B}^{\mathrm{IEF}}$ is present in milks with higher casein content than $\mathrm{A}^{\mathrm{IEF}}$.

The variant $\mathrm{D}$ (formerly B) of $\kappa$-cn predominated in the samples analyzed by ESI$\mathrm{MS}$, as happens with the majority of the European goat breeds $[6,44,50]$. In 2 samples out of 25 , there was a mass attributed to $\kappa$ cn $\mathrm{G}$ found in Italian and Turkish breeds $[39,50]$. The major form of $\kappa-C n$ was the $2 \mathrm{P}$ form, although the $1 \mathrm{P}$ form was also evident, as previously reported $[35,38,48]$.

\subsection{Whey proteins}

The ratio $\beta-\mathrm{Lg} / \alpha-\mathrm{La}$ was $1.58 \pm 0.33$ and in the majority of samples (49 out of 57) it 
ranged from 1.1 to 1.9 . The $\alpha$-La mass detected by RP-HPLC/ESI-MS analyses was $14198 \pm 1$, which corresponds to the theoretical mass of goat $\alpha$-La (14 192.2). The mass $18197 \pm 1$ detected in the $\beta$ - $\mathrm{Lg}$ peaks of the milks of the present study corresponds to the theoretical mass of this goat protein (18 191.3). In some samples a mass of $18523 \pm 1$ was detected in the front part of the $\beta-\operatorname{Lg}$ peak that is consistent with a covalent linkage of lactosyl residue to the protein $[24,48]$. No protein variants were observed, in accordance with the previous works that report only silent alleles for goat $\alpha$-La [11] and $\beta$-Lg loci [2, 19, 36, 49].

\section{CONCLUSION}

The goat's milk of the autochthonous Skopelos breed had a higher total protein content and a higher $\alpha_{\mathrm{s} 1}$-cn content compared with the milk of international breeds. This characteristic was consistent with predominance of the strong $\alpha_{\mathrm{s} 1}$-cn variants B3, B4 and As/B1. The most frequent $\alpha_{\mathrm{s} 2}$-cn variant was by far variant $A$ followed by variants $\mathrm{C}$ and $\mathrm{F}$, whereas compositional data showed the existence of a null allele. The detected $\beta$-cn forms were variants A and $\mathrm{C}$ in similar frequencies. Variant $\mathrm{D}$ (formerly B) of $\kappa$-cn predominated and the rare variant $\mathrm{G}$ was found.

Therefore, according to the findings of the present study, the milk of the Skopelos breed is a "strong" milk suitable for cheesemaking, although further studies with respect to micelle characteristics are needed. Furthermore, it can be concluded that the RP-HPLC analysis of defatted milk can be a simple and fast way to study with reasonable certainty the complex characteristics of the goat protein fraction by taking into consideration the RT and the quantity of the peaks.

Acknowledgements: This study was a part of the research project "Projets communs de Recherche et de Technologie, France-Grèce, 2003-2006" founded by the Greek General Secretariat for Research and Technology of the Ministry of Development (ЕПАv M. 4.3.6.1).

\section{REFERENCES}

[1] Anifantakis E.M., Kandarakis I.J., Contribution to the study of the composition of goat's milk, Milchwissenschaft 35 (1980) 617-619.

[2] Ballester M., Sánchez A., Folch J.M., Polymorphisms in the goat $\beta$-lactoglobulin gene, J. Dairy Res. 72 (2005) 1-6.

[3] Bevilacqua C., Martin P., Candahl C., Fauquant J., Piot M., Roucayrol A.M., Pilla F., Heyman M., Goats' milk of defective $\alpha_{\mathrm{s} 1}$-casein genotype decreases intestinal and systemic sensitization to $\beta$-lactoglobulin in guinea pigs, J. Dairy Res. 68 (2001) 217227.

[4] Bevilacqua C., Ferranti P., Garro G., Veltri C., Lagonigro R., Leroux C., Pietrolá E., Addeo F., Pilla F., Chianese L., Martin P., Interallelic recombination is propably responsible for the occurrence of a new $\alpha_{\mathrm{s} 1^{-}}$ casein variant found in the goat species, Eur. J. Biochem. 269 (2002) 1293-1303.

[5] Bouniol C., Brignon G., Mahé M.F., Printz C., Biochemical and genetic analysis of variant $C$ of caprine $\alpha_{\mathrm{s} 2}$-casein (Capra hircus), Anim. Genet. 25 (1994) 173-177.

[6] Chessa S., Budelli E., Gutscher K., Caroli A., Erhadt G., Short communication: Simultaneous identification of five $\kappa$-casein (CSN3) alleles in domestic goat by polymerase chain reaction-single strand conformation polymorphism, J. Dairy Sci. 86 (2003) 3726-3729.

[7] Chessa S., Budelli E., Chiatti F., Cito A.M., Bolla P., Caroli A., Short Communication: Predominance of $\beta$-casein (CSN2) $\mathrm{C}$ allele in goat breeds reared in Italy, J. Dairy Sci. 88 (2005) 1878-1881.

[8] Chianese L., Portolano B., Troncone E., Pizzolongo F., Ferranti P., Addeo F., Alicata M.L., Pilla F., Galagna G., The quality of Girgentana goat milk, in: Proceedings of the 7th International Conference on Goats, Tours, France, 15-21 May 2000, pp. 946-949.

[9] Clark S., Sherbon J.W., Alpha ${ }_{\mathrm{s} 1}$-casein milk composition and coagulation properties of goat milk, Small Ruminant Res. 38 (2000) 123-134.

[10] Clark S., Sherbon J.W., Genetic variants of alpha $_{\mathrm{s} 1}$-cn in goat milk: breed distribution and associations with milk composition and coagulation properties, Small Ruminant Res. 38 (2000) 135-143.

[11] Cosenza G., Gallo D., Illario R., Di Gregorio P., Senese C., Ferrara L., Ramunno L., A 
Mval PCR-RFLP detecting a silent allele at the goat $\alpha$-lactalbumin locus, J. Dairy Res. 67 (2003) 217-224

[12] Cosenza G., Pauciullo A., Gallo D., Di Berardino D., Ramunno L., A Sspl PCRRFLP detecting a silent allele at the goat CSN2 locus, J. Dairy Res. 72 (2005) 1-4.

[13] Cunsolo V., Galliano F., Muccilli V., Saletti R., Marletta D., Bordorano S., Foti S., Detection and characterization by high-performance liquid chromatography and mass spectrometry of a goat $\beta$-casein associated with CSN2 null allele, Rapid Commun. Mass Spectrom. 19 (2005) 2943-2949.

[14] Enne G., Feligini M., Greppi G.F., Iametti S., Pagani S., Gene frequencies of caprine $\alpha_{s 1}$-casein polymorphism in dairy goat, in: Proceedings of International Dairy Federation Seminar, on Milk Protein Polymorphism, Palmerston North, New Zealand, Int. Dairy Fed. Special Issue 9702, 1997, pp. 275-279.

[15] Erhardt G., Jäger S., Budelli E., Caroli A., Genetic polymorphism of goat $\alpha_{\mathrm{s} 2}$-casein $\left(\mathrm{CSN}_{\mathrm{S} 2}\right)$ and evidence for a further allele, Milchwissenschaft 57 (2002) 137-140.

[16] Ferranti P., Lilla S., Chianese L., Addeo F., Alternative nonallelic deletion is constitutive of ruminant $\alpha_{\mathrm{s} 1}$-casein, J. Protein Chem. 18 (1999) 595-602.

[17] Galliano F., Saletti R., Cunsolo V., Foti S., Marletta D., Bordorano S., D'Urso G., Identification and characterization of a new $\beta$-casein variant in goat milk by high-performance liquid chromatography with electrospray ionization mass spectrometry and matrix-assisted laser desorption/ionization mass spectrometry, Rapid Commun. Mass Spectrom. 18 (2004) 1972-1982.

[18] Gourgoulis M., Rogdakis E., Genetic structure of Indigenous goat populations of Greece: IV. Genetic variability between populations, Anim. Sci. Rev. 27 (2000) 15-25.

[19] Graziano M., D’Andrea M., Angiolillo A., Lagonigro R., Pilla F., A new polymorphism in goat $\beta$-lactoglobulin promoter region, Ital. J. Anim. Sci. 1 (2003) 65-68.

[20] Jann O.C., Prinzenberg E.-V., Luikart G., Caroli A., Erhardt G., High polymorphism in the $\mathrm{K}$-casein $(\mathrm{CSN} 3)$ gene from wild and domestic goat species revealed by DNA sequencing, J. Dairy Res. 71 (2004) 188-195.

[21] Jaubert A., Martin P., Reverse-phase HPLC analysis of goat caseins: Identification of $\alpha_{\mathrm{s}}$ and $\alpha_{s 2}$ genetic variants, Lait 72 (1992) 235-247.
[22] Jordana J., Amills M., Diaz E., Angulo C., Serradilla J.M., Sanchez A., Gene frequencies of caprine $\alpha_{\mathrm{s} 1}$-casein polymorphism in Spanish goat breeds, Small Ruminant Res. 20 (1996) 215-221.

[23] Lagonigro R., Pietrola E., D’Andrea M., Veltri C., Pilla F., Molecular genetic characterization of the goat $\alpha_{\text {s }}$-casein $\mathrm{E}$ allele, Anim. Genet. 32 (2001) 390-393.

[24] Léonil J., Mollé F., Fauquant J., Maubois J.L., Pearce R.J., Bouhallab S., Characterization by ionization mass spectrometry of lactosyl $\beta$-lactoglobulin conjugates formed during heat treatment of milk and whey and identification of one lactose-binding site, $\mathrm{J}$. Dairy Sci. 80 (1997) 2270-2281.

[25] Mahé M.F., Grosclaude F., Polymorphism of $\beta$-casein in the Creole goat of Guadeloupe: evidence for a null allele, Genet. Sel. Evol. 25 (1993) 403-408.

[26] Marletta D., Bordonaro S., Guastella A.M., D'Urso G., Genetic polymorphism at $\mathrm{CSN1}_{\mathrm{S} 2}$ locus in two endangered Sicilian goat breeds, J. Anim. Breed. Genet. 121 (2004) 52-56.

[27] Marletta D., Bordonaro S., Guastella A.M., Criscione A., D'Urso G., Genetic polymorphism of the calcium sensitive caseins in Sicilian Girgentanta and Argentata dell'Etna goat breeds, Small Ruminant Res. 57 (2005) 133-139.

[28] Martin P., Ollivier-Bousquet M., Grosclaude F., Genetic polymorphism of caseins: a tool to investigate casein micelle organization, Int. Dairy J. 9 (1999) 163-171.

[29] Mercier J.F., Phosphorylation of casein: Present evidence for an amino acid triplet code posttranslational recognized by specific kinases, Biochimie 63 (1981) 1-17.

[30] Moatsou G., Hatzinaki A., Kandarakis I., Anifantakis E., Nitrogenous fractions during the manufacture of whey protein concentrates from Feta cheese whey, Food Chem. 81 (2003) 209-217.

[31] Moatsou G., Samolada M., Katsabeki A., Anifantakis E., Casein fraction of ovine milk from indigenous Greek breeds, Lait 84 (2004) 285-296.

[32] Moreno F.J., Recio I., Olano A., López-Fandiňo R., Heterogeneity of caprine $\kappa$-casein macropeptide, J. Dairy Res. 68 (2001) 197-208.

[33] Morgan F., Jacquet F., Micault S., Bonnin V., Jaubert A., Study of the compositional factors involved in the variable sensitivity of caprine milk to high-temperature processing, Int. Dairy J. 10 (2000) 113-117. 
[34] Morgan F., Massouras T., Barbosa M., Roseiro L., Ravasco F., Kandarakis I., Bonnin V., Fiskatoris M., Anifantakis E., Jaubert G., Raynal-Ljutovac K., Characteristics of goat milk collected from small and medium enterprises in Greece, Portugal and France, Small Ruminant Res. 47 (2003) 39-49.

[35] Neveu C., Mollé D., Moreno J., Martin P., Léonil J., Heterogeneity of caprine betacasein elucidated by RP-HPLC/MS: Genetic variants and phosphorylations, J. Protein Chem. 21 (2002) 557-567.

[36] Pena R.N., Sánchez A., Folch J.M., Characterization of genetic polymorphism in the goat $\beta$-lactoglobulin gene, J. Dairy Res. 67 (2000) 217-224.

[37] Persuy M.-A., Printz C., Medrano J.F., Mercier J.-C., A single nucleotide deletion resulting in a premature stop codon is associated with marked reduction of transcripts from a goat $\beta$-casein null allele, Anim. Genet. 30 (1999) 444-451.

[38] Pierre A., Mollé D., Zahoute L., Characterization of the casein variants in goat bulk milks using on-line RP-HPLC / ESI-MS, Lait 81 (2001) 667-678.

[39] Prinzenberg E.-V., Gutscher K., Chessa S., Caroli A., Erhardt G., Goat K-casein (CSN3) polymorphism: new developments in molecular knowledge, J. Dairy Sci. 88 (2005) 1490-1498.

[40] Ramunno L., Longobardi E., Pappalardo M., Rando A., Di Gregorio P., Conzenza G., Mariani P., Pastore N., Masina P., An allele associated with a non-detectable amount of $\alpha_{\mathrm{s} 2}$ casein in goat milk, Anim. Genet. 32 (2001) 19-26.

[41] Ramunno L., Cosenza G., Pappalardo M., Longobardi E., Gallo D., Pastrore N., Di Gregorio P., Rando A., Characterization of two new alleles at the goat $\mathrm{CSN}_{\mathrm{S} 2}$ locus, Anim. Genet. 32 (2001) 264-268.
[42] Ramunno L., Cosenza G., Rando A., Pauciullo A., Illario R., Gallo D., Di Berardino D., Masina P., Comparative analysis of gene sequence of goat $\mathrm{CSN}_{\mathrm{S} 1} \mathrm{~F}$ and $\mathrm{N}$ alleles and characterization of $\mathrm{CSN}_{\mathrm{S} 1}$ transcript variants in mammary gland, Gene 345 (2005) 289-299.

[43] Roberts B., Di Tullio P., Vitale J., Hehir K., Gordon K., Cloning of the goat $\beta$-caseinencoding gene and expression in transgenic mice, Gene 121 (1992) 255-262.

[44] Sacchi P., Chessa S., Budelli E., Bolla P., Ceriotti G., Soglia D., Pasero R., Cauvin E., Caroli A., Casein haplotype structure in five Italian goat breeds, J. Dairy Sci. 88 (2005) $1561-1568$.

[45] Simos E., Voutsinas L.P., Pappas C.P., Composition of milk of native Greek goats in the region of Metsovo, Small Ruminant Res. 4 (1991) 47-60.

[46] St-Gelais D., Turcot S., Ali A.O.B., Chemical composition and properties of milk from five goat breeds, Milchwissenschaft 60 (2005) 140-143

[47] Tadlaoui Ouafi A., Babilliot J.-M., Leroux C., Martin P., Genetic diversity of two main Moroccan goat breeds: phylogenetic relationships with four breeds reared in France, Small Ruminant Res. 45 (2002) 225-233.

[48] Trujillo A.J., Casals I., Guamis B., Analysis of major caprine milk proteins by ReversePhase High-Performance Liquid Chromatography and Electrospray Ionization-Mass Spectrometry, J. Dairy Sci. 83 (2000) 11-19.

[49] Yahyaoui M.H., Pena R.N., Sánchez A., Folch J.M., Rapid communication: polymorphism in the goat beta-lactoglobulin proximal promoter region, J. Anim. Sci. 78 (2000) $1100-1101$.

[50] Yahyaoui M.H., Angiolillo A., Pilla F., Sanchez A., Folch J.M., Characterization and genotyping of the goat $\kappa$-casein variants, J. Dairy Sci. 86 (2003) 2715-2720. 